\title{
Manajemen Penerapan Kurikulum 2013 di MTs AL-WASHLIYAH 30 Pematan Guntung Kecamatan Teluk Mengkudu Kabupaten Serdang Bedagai
}

\author{
Mayasari $^{1 *}$, Mahanum ${ }^{2}$, Usiono, $^{3}$ \\ ${ }^{1}$ (Universitas Islam Negeri Sumatera Utara Medan) \\ ${ }^{3}$ (Universitas Islam Negeri Sumatera Utara Medan) \\ ${ }^{2}$ (Universitas Islam Negeri Sumatera Utara Medan) \\ * Corresponding Author. E-mail: mayya180490@gmail.com
}

Receive: 13/05/2021

Accepted: 23/08/2021

Published: 01/10/2021

\begin{abstract}
Abstrak
Penelitian ini dilaksanakan di MTs Al Washliyah 30 Pematang Guntung Kecamatan Teluk Mengkudu Kabupaten Serdang Bedagai, jenis penelitian ini adalah penelitian kualitatif. Sebagai informan dalam penelitian ini adalah Wakil Kepala Madrasah bagian kurikulum. Pengumpulan data menggunakan metode observasi, wawancara dan dokumentasi. Analisis data dilakukan dengan cara Reduksi Data, Penyajian Data dan Penarikan Kesimpulan (verifikasi). Penelitian ini bertujuan untuk sebagai berikut, (1) Untuk mengetahui manajemen penerapan kurikulum 2013. (2) Untuk mengetahui kendala yang dialami pada saat penerapan kurikulum 2013. Hasil penelitian menunjukkan bahwa (1) Penerapan kurikulum 2013 dilaksanakan atas dasar Permendikbud Nomor. 160 tahun 2014 tentang pemberlakuan kurikulum 2006 dan kurikulum 2013 dan dilaksanakan sesuai juknis Keputusan Menteri Agama Nomor. 207 tahun 2014 tentang struktur implementasi kurikulum madrasah disimpatika. (2) Mewajibkan seluruh pendidik untuk melengkapi administrasi seperti silabus, KKM, Program Semester (PROTA), Program Semester (PROSEM), Rencana Perangkat Pembelajaran (RPP), Penilaian dan lainlain. (3) Langkah yang diambil dalam penerapan kurikulum 2013 ini adalah mengikuti juknis Kementerian Agama, mengikuti struktur kurikulum 2013 yang diberlakukan berdasarkan Permendikbud. (4) Kendala yang dialami saat penerapan kurikulum 2013 di madrasah tersebut ialah kurangnya pelatihan-pelatihan pada pendidik dalam penerapan kurikulum 2013.
\end{abstract}

Kata Kunci: Manajemen, Kurikulum, Al-Washliyah

\begin{abstract}
English-Indonesia)
This research was conducted at MTs Al Washliyah 30 Pematang Guntung Teluk Mengkudu District, Serdang Bedagai Regency, this type of research is a qualitative research. As an informant in this study was the Deputy Head of the Madrasah curriculum section. Collecting data using the method of observation, interviews and documentation. Data analysis was carried out by means of data reduction, data presentation and conclusion drawing (verification). This study aims to: (1) To find out the management of the 2013 curriculum implementation. (2) To find out the obstacles experienced during the 2013 curriculum implementation. The results showed that (1) The 2013 curriculum implementation was carried out on the basis of Permendikbud No. 160 of 2014 concerning the implementation of the 2006 curriculum and the 2013 curriculum and implemented according to the technical guidelines of the Minister of Religion Decree No. 207 of 2014 concerning the structure of the implementation of the sympathetic madrasa curriculum. (2) Require all educators to complete administration such as syllabus, KKM, Semester Program (PROTA), Semester Program (PROSEM), Learning Device Plan (RPP), Assessment and others. (3) The steps taken in implementing the 2013 curriculum are following the technical guidelines of the Ministry of Religion, following the 2013 curriculum structure that is enforced based on the Permendikbud. (4) The obstacle experienced when implementing the 2013 curriculum in the madrasa is the lack of training for educators in implementing the 2013 curriculum.
\end{abstract}

Keywords: Management, Curriculum, Al-Washliyah 


\section{Pendahuluan}

Menurut James A.F Stoner yang mendefenisikan manajemen sebagai proses perencanaan, pengorganisasian, dan penggunaan sumber daya organisasi lainnya agar mencapai tujuan organisasi yang telah ditetapkan. Menajemen sebagai seni pencapaian tujuan yang dilakukan melalui usaha orang lain. Manejemen berasal dari bahasa Inggris to manage yang berarti mengatur, mengurus, atau mengelola. Menurut Malayu, S.P. Hasibuan, manajemen adalah ilmu dan seni mengatur proses pemanfaatan sumber daya manusia secara efektif, yang didukung oleh sumber-sumber lain dalam organisasi untuk mencapai tujuan tertentu .Menurut James A.F Stoner yang mendefenisikan manajemen sebagai proses perencanaan, pengorganisasian, dan penggunaan sumber daya organisasi lainnya agar mencapai tujuan organisasi yang telah ditetapkan. Manajemen sebagai seni pencapaian tujuan yang dilakukan melalui usaha orang lain (Porro 2016).

Dalam manajemen terdapat prinsipprinsip yang merupakan pedoman umum atau pegangan utama pelaksanaan aktifitas menajerial, yang menentukan kesuksesan pengelolaan organisasi. Roda organisasi atau perusahaan dipacu dengan melaksanakan berbagai kegiatan yang berprinsip pada prinsip-prinsip yang umum dalam menajemen (Zaini and Syafaruddin 2020).Islam menetapkan bahwa manajemen merupakan aktivitas yang berlandaskan nilai-nilai keadilan, yang merupakan perbuatan pimpinan yang tidak menyakiti atau menzalimi bawahan. Dalam ajaran Islam, manajemen dipandang sebagai perwujudan amal saleh yang harus bertitik tolak dari niat baik. Niat baik tersebut akan memunculkan motivasi aktivitas untuk mencapai hasil yang optimal demi kesejahteraan bersama. Nabi Muhammad, SAW. Mengelola serta mempertahankan kerja sama dengan sahabatnya dalam waktu yang lama. Salah satu kebiasaan Nabi adalah memberikan reward atas kreativitas serta prestasi yang ditunjukkan sahabatnya (Sani 2014). Islam menetapkan bahwa manajemen merupakan aktivitas yang berlandaskan nilai-nilai keadilan, yang merupakan perbuatan pimpinan yang tidak menyakiti atau menzalimi bawahan. Dalam ajaran Islam, manajemen dipandang sebagai perwujudan amal saleh yang harus bertitik tolak dari niat baik. Niat baik tersebut akan memunculkan motivasi aktivitas untuk mencapai hasil yang optimal demi kesejahteraan bersama.

Perkembangan manajemen dalam Islam merupakan realitas yang tidak dapat dipungkiri oleh sejarah peradaban manusia di dunia. Karena Islam dengan Al Qur'an dan Sunnahnya mengajarkan cara-cara pengelolaan kehidupan yang baik. Islam menetapkan manajemen diri dan manajemen kelembagaan sebagai bagian dari kewajiban masyarakat. Salah satu bukti konkret adalah keharusan mencatat utang piutang, membangun lembaga pendidikan yang kondusif, serta menjadi pemimpin yang adil, amanah, jujur, dan cerdas dalam memutuskan perkara.

Pembelajaran pada kurikulum 2013 berbeda dengan kurikulum-kurikulum sebelumnya. Sebab, pembelajaran pada kurikulum ini lebih menggunakan pendekatan ilmiah dan tematik-integratif. Proses pembelajaran pada satuan pendidikan diselenggarakan secara interaktif, inspiratif, menyenangkan, menantang, dan memotivasi peserta didik untuk berpartisipasi aktif, serta memberikan ruang yang cukup bagi prakarsa, kreativitas, dan kemandirian sesuai dengan bakat, minat, dan perkembangan fisik serta psikologi peserta didik.

Kurikulum 2013 berupaya secara konsisten untuk memenuhi janji dunia pendidikan terhadap bangsa ini. Janji sebagaimana yang dituangkan dalam undangundang sistem pendidikan nasional, yaitu " pendidikan adalah usaha sadar dan terencana untuk mewujudkan suasana belajar dan proses pembelajaran agar peserta didik secara aktif mengembangkan potensi dirinya untuk memiliki kekuatan spiritual keagamaan, 
pengendalian diri, kepribadian, kecerdasan, akhlak mulia, serta keterampilan yang diperlukan dirinya, masyarakat, bangsa dan Negara". Pembelajaran pada kurikulum 2013 berbeda dengan kurikulum-kurikulum sebelumnya. Sebab, pembelajaran pada kurikulum ini lebih menggunakan pendekatan scientifik (ilmiah). Proses pembelajaran pada satuan pendidikan diselenggarakan secara interaktif, inspiratif, menyenangkan, menantang, dan kemandirian sesuai dengan bakat, minat, dan perkembangan fisik serta psikologis peserta didik (Depdikbud 1998).

$$
\text { Kurikulum } 2013 \text { merupakan }
$$

kurikulum baru yang mulai diterapkan pada tahun pelajaran 2013/2014. Kurikulum ini adalah pengembangan dari dari kurikulum yang telah ada sebelumnya, baik Kurikulum Berbasis Kompetensi yang telah dirintis pada tahun 2004 maupun Kurikulum Tingkat Satuan Pendidikan pada tahun 2006. Hanya saja yang menjadi titik tekan pada Kurikulum 2013ini adalah adanya peningkatan dan keseimbangan soft skills dan hard skills yang meliputi aspek kompetensi sikap, keterampilan, dan pengetahuan. Kurikulum 2013 merupakan kurikulum baruyang lebih menekankan untuk tercapainya kompetensi sikap, pengetahuan, dan keterampilan yang semuanya terangkum dalam kompetensi pembelajaran yang ideal strategi maupun metode pembelajaran yang menyenangkan, kontektual, efektif dan efesien serta memiliki kebermaknaan bagi peserta didik. Pelaksanaan pembelajaran kurikulum 2013 terbagi menjadi tiga, yaitu kegiatan awal, kegiatan inti, dan kegiatan akhir. Ketiga kegiatan tersebut tersusun menjadi satu dalam suatu kegiatan pembelajaran dan tidak dapat dipisah-pisahkan satu dengan yang lain.

Ruang lingkup penilaian dalam kurikulum 2013 terdapat tiga komponen utama, yaitu penilaian sikap, pengetahuan, dan keterampilan. Ketiga komponen tersebut dilaksanakan dengan menggunakan tehnik dan instrumen penilaian yang berbeda-beda, tetapi tetap berimbang dan berfungsi salingmelengkapi antara satu dengan yang lain. Hasil dari penilaian ketiga komponen tersebut dapat dijadikan sebagai tolak ukur dalam menentukan keberhasilan peserta didik dalam mengikuti proses pembelajaran (Hamalik 2008; Majid and Rochman 2014).

$$
\text { Kurikulum } 2013 \text { di MTs Al }
$$

Washliyah 30 Pematang Guntung Kecamatan Teluk Mengkudu Kabupaten Serdang Bedagai mulai diterapkan pada tahun 2016. Selama penerapan tersebut banyak kendala yang dialami oleh lembaga pendidikan, pendidik, maupun peserta didik. Karena, konsep pembelajaran pada kurikulum 2013 ini sangat berbeda dengan kurikulum yang dipakai sebelumnya. Dalam penerapan kurikulum 2013 ini siswa diajarkan untuk lebih berperan aktif dikelas dalam mengembangkan potensi mereka menjadi kemampuan dalam sikap, pengetahuan, dan keterampilan yang diperlukan untuk hidup dan bermasyarakat, berbangsa, serta berkontribusi pada kesejahteraan hidup umat manusia.

Dalam manajemen penerapan kurikulum 2013 di MTs Al Washliyah 30 Pematang Guntung Kecamatan Teluk Mengkudu Kabupaten Serdang Bedagai setiap pendidik diwajibkan memiliki Rencana Pelaksanaan Pembelajaran yang biasa disebut dengan RPP. Dengan adanya RPP tersebut memudahkan pendidik untuk memberikan pembelajaran kepada peserta didiknya. Dan pendidik juga diwajibkan mempunyai kreatifitas dalam mengembangkan pembelajaran agar peserta didik termotivasi dalam belajar.

Berdasarkan kenyataan di MTs Al Washliyah Pematang Guntung Kecamatan Teluk Mengkudu Kabupaten Serdang Bedagai tersebut maka, perlu dilakukan penelitian untuk mengetahui adakah kendala yang dialami pendidik maupun peserta didik pada saat penerapan kurikulum 2013 pada paparan latar belakang diatas, maka peneliti mengambil judul penelitian yaitu: “ Manajemen Penerapan Kurikulum 2013 di MTs Al Washliyah Pematang Guntung Kecamatan Teluk Mengkudu Kabupaten Serdang Bedagai".

\section{Metode}


Penelitian kualitatif adalah penelitian yang menggunakan latar alamiah, dengan maksud menafsirkan fenomena yang terjadi dan dilakukan dengan jalan melibatkan berbagai metode yang ada. Untuk sumber penelitian kali ini yaitu mengacu pada katakata, dan tindakan, selebihnya adalah data tambahan seperti dokumen dan lain-lain. Adapun dalam pengumpulan data dilakukan dengan menggunakan metode wawancara, Observasi dab Studi dokumentasi. Untuk teknik analisis data dilakukan dengan Mereduksi data, Penyajian Data, dan Verifikasi Data,

\section{Hasil dan Pembahasan Hasil Penelitian}

Sebagai lembaga pendidikan yang baru menggunakan kurikulum 2013, tentunya masih banyak kekurangan dalam penerapan kurikulum 2013 tersebut.

Kepala Madrasah juga harus mempunyai strategi yang sangat penting agar manajemen penerapan kurikulum 2013 di MTs Al Washliyah 30 Pematang Guntung Kecamatan Teluk Mengkudu Kabupaten Serdang Bedagai berjalan sesuai dengan juknis Kementerian Agama dan sesuai dengan yang diharapkan oleh Madrasah.

Kepala Madrasah juga harus menegaskan kepada setiap pendidik agar segala administrasi dalam manajemen penerapan kurikulum 2013 dan dapat menjalankan tugasnya sebagai pendidik dengan baik.

Selain itu, tugas kepala madrasah dalam menjalankan manajemen penerapan kurikulum 2013 untuk meningkatkan pendidikan yang berkualitas dan menghasilkan peserta didik yang berprestasi.

Hasil wawancara dengan wakil kepala madrasah bagian kurikulum Ibu Nur Ainun, S.Ag tentang manajemen penerapan kurikulum 2013 di MTs Al Washliyah 30 Pematang Guntung Kabupaten Serdang Bedagai yaitu sebagai berikut:
"Dalam manajemen penerapan kurikulum 2013 di MTs Al Washliyah 30 Pematang Guntung Kecamatan Teluk Mengkudu Kabupaten Serdang Bedagai kepala madrasah mewajibkan setiap pendidik untuk melengkapi segala administrasi seperti silabus, KKM, Program Tahunan (PROTA), Program Semester (PROSEM), Rencana Perangkat Pembelajaran (RPP), Penilaian dan lain-lain guna tercapainya tujuan pendidikan yang lebih baik."

Dari hasil wawancara wakil kepala madrasah bahwa manajemen penerapan kurikulum 2013 tersebut berjalan dengan baik setiap pendidik mempunyai kelengkapan administrasi, maka dari itu saya sebagai peneliti ingin menanyakan kembali kepada wakil kepala madrasah, bagaimana penerapan kurikulum 2013 di MTs Al Washliyah 30 Pematang Guntung Kecamatan Teluk Mengkudu Kabupaten Serdang Bedagai. Adapun hasil wawancara saya dengan wakil kepala madrasah yaitu :

"Saya selaku wakil kepala madrasah, telah mementau perkembangan penerapan kurikulum 2013 ini. Penerapan kurikulum 2013 dilaksanakan atas dasar Permendikbud Nomor. 16 tahun 2014 tentang pemberlakuan Kurikulum 2006 dan Kurikulum 2013. Dan dilaksanakannya berpedoman dengan petunjuk teknis Keputusan Menteri Agama Nomor. 207 tahun 2014 tentang standar implementasi kurikulum madrasah di simpatika. Dalam penerapannya sejauh ini diupayakan dengan sebaik-baiknya."

Dari hasil wawancara wakil kepala madrasah bahwa penerapan kurikulum 2013 sudah berjalan dengan baik, hanya saja karena penerapan ini baru dilaksanakan hasil yang diinginkan belum tercapai sesuai dengan tujuan. Dan penerapan kurikulum 2013 dengan kurikulum sebelumnya sangat jauh berbeda. Maka dari itu saya sebagai peneliti ingin bertanya kembali kepada wakil kepala madrasah bagian kurikulum tentang kendala yang dialami pada saat penerapan kurikulum 2013. Dan hasil dari wawancara wakil kepala madrasah bagian kurikulum sebagai berikut: "Dalam penerapan kurikulum 2013 ini ada sedikit banyaknya kendala yang dialami yaitu 
kurangnya pelatihan-pelatihan kepada pendidik dalam penerapan kurikulum 2013. Jadi, dalam hal ini masih banyak pendidik yang kurang paham bagaimana penerapan kurikulum 2013 yang benar dan dari segi administrasi masih ada juga sebagaian yang belum mengerti cara pembuatannya sendiri, masih dengan bantuan orang lain. Kurangnya media pembelajaran menjad salah satu kendala yang dialami selama penerapan kurikulum 2013 ini”.

Dari hasil wawancara wakil kepala madrasah bahwa kendala yang dialami cukup banyak dalam penerapan kurikulum 2013 di MTs AL Washliyah 30 Pematang Guntung Kecamatan Teluk Mengkudu Kabupaten Serdang Bedagai. Maka dari itu saya ingin bertanya kepada salah satu guru bidang studi sejarah kebudayaan Islam Ibu Sarifah Khairani, S.Pd.I tentang penerapan kurikulum 2013 yang dilakukan pada saat belajar mengajar. Adapun hasil wawancaranya adalah sebagai berikut:

"Saya selaku guru bidang studi sejarah kebudayaan Islam, selama diterapkannya kurikulum 2013 ini, dapat mempermudah proses belajar dan mengajar karena dalam pembelajaran kurikulum 2013 menuntut agar peserta didik menjadi lebih aktif, berkembang, memiliki wawasan yang luas, kreatif, dan lebih percaya diri dalam menyampaikan pendapat. Selama penerapan kurikulum 2013 ini manajemen penerapan kurikulum 2013 menjadi semakin baik hampir seluruh pendidik menjadi lebih sadar akan tugasnya sebagai pendidik yang harus melengkapi segala administrasi yang diperlukan pada saat proses belajar mengajar berlangsung."

Dari hasil wawancara dengan guru bidang studi sejarah Kebudayaan Islam bahwa penerapan kurikulum 2013 ini ada sisi positifnya. Karena mempermudah dalam pelaksanaan proses pembelajaran dan menjadikan peserta didik yang aktif, kreatif, berwawasan yang luas dan lebih percaya diri dalam menyampaikan pendapat. dan saya bertanya kembali kepada guru bidang studi sejarah kebudayaan Islam tentang kendala yang dialam pada saat penerapan kurikulum
2013 ini. Adapun hasil wawancaranya adalah sebagai berikut:

"Kendala yang saya alami pada saat penerapan kurikulum 2013 ini hanya dalam penguasaan materi dan metode yang digunakan pada saat pembelajaran berlangsung. Tidak semua peserta didik pemikirannya sama, karena ada sebagian peserta didik yang kurang aktif apabila menggunakan metode ceramah dia paham dan saat diberi tugas untuk diskusi dia masih tidak mengerti. Jadi sebagai pendidik harus bisa melihat perkembangan setiap peserta didik."

Dari hasil wawancara tersebut bahwa kendala yang dialami cukup beragam. Karena memang penerapan kurikulum 2013 ini masih termasuk baru dan penerapan kurikulum 2013 cukup berbeda dari kurikulum sebelumnya dan masih banyak yang belum memahami penerapan kurikulum 2013 ini.

\section{Pembahasan \\ Manajemen penerapan kurikulum 2013}

Sebagai lembaga pendidikan yang baru menggunakan kurikulum 2013, tentunya masih banyak kekurangan dalam penerapan kurikulum 2013 tersebut.

Kepala Madrasah juga harus mempunyai strategi yang sangat penting agar manajemen penerapan kurikulum 2013 di MTs Al Washliyah 30 Pematang Guntung Kecamatan Teluk Mengkudu Kabupaten Serdang Bedagai berjalan sesuai dengan juknis Kementerian Agama dan sesuai dengan yang diharapkan oleh Madrasah.

Kepala Madrasah juga harus menegaskan kepada setiap pendidik agar segala administrasi dalam manajemen penerapan kurikulum 2013 dan dapat menjalankan tugasnya sebagai pendidik dengan baik guna tercapainya tujuan pendidikan yang sesuai dengan penerapan kurikulum 2013.

Selain itu, tugas kepala madrasah dalam menjalankan manajemen penerapan kurikulum 2013 untuk meningkatkan pendidikan yang berkualitas dan menghasilkan peserta didik yang berprestasi (Siregar, Syafaruddin, and Zaini 2020). 


\section{Penerapan Kurikulum 2013}

Penerapan

kurikulum

dilaksanakan atas dasar Permendikbud Nomor. 16 tahun 2014 tentang pemberlakuan Kurikulum 2006 dan Kurikulum 2013. Dan dilaksanakannya berpedoman dengan petunjuk teknis Keputusan Menteri Agama Nomor. 207 tahun 2014 tentang standar implementasi kurikulum madrasah di simpatika. Dalam penerapannya sejauh ini diupayakan dengan sebaik-baiknya. selama diterapkannya kurikulum 2013 ini, dapat mempermudah proses belajar dan mengajar karena dalam pembelajaran kurikulum 2013 menuntut agar peserta didik menjadi lebih aktif, berkembang, memiliki wawasan yang luas, kreatif, dan lebih percaya diri dalam menyampaikan pendapat. Selama penerapan kurikulum 2013 ini manajemen penerapan kurikulum 2013 menjadi semakin baik hampir seluruh pendidik menjadi lebih sadar akan tugasnya sebagai pendidik yang harus melengkapi segala administrasi yang diperlukan pada saat proses belajar mengajar berlangsung (Hamalik 2003).

\section{Kendala saat Penerapan Kurikulum 2013}

Dalam penerapan kurikulum 2013 ini ada sedikit banyaknya kendala yang dialami yaitu kurangnya pelatihan-pelatihan kepada pendidik dalam penerapan kurikulum 2013. Jadi, dalam hal ini masih banyak pendidik yang kurang paham bagaimana penerapan kurikulum 2013 yang benar dan dari segi administrasi masih ada juga sebagaian yang belum mengerti cara pembuatannya sendiri, masih dengan bantuan orang lain. Kurangnya media pembelajaran menjad salah satu kendala yang dialami selama penerapan kurikulum 2013 ini. Kendala yang sering dialami pada saat penerapan kurikulum 2013 ini hanya dalam penguasaan materi dan metode yang digunakan pada saat pembelajaran berlangsung. Tidak semua peserta didik pemikirannya sama, karena ada sebagian peserta didik yang kurang aktif apabila menggunakan metode ceramah dia paham dan saat diberi tugas untuk diskusi dia masih tidak mengerti. Jadi sebagai pendidik harus bisa melihat perkembangan setiap peserta didik (Zaini 2019).

\section{Simpulan}

Pelaksanaan manajemen penerapan kurikulum 2013 menegaskan kepada setiap pendidik agar segala administrasi dalam manajemen penerapan kurikulum 2013 dan dapat menjalankan tugasnya sebagai pendidik dengan baik guna tercapainya tujuan pendidikan yang sesuai dengan penerapan kurikulum 2013. Selain itu, tugas kepala madrasah dalam menjalankan manajemen penerapan kurikulum 2013 untuk meningkatkan pendidikan yang berkualitas dan menghasilkan peserta didik yang berprestasi. Penerapan kurikulum 2013 dilaksanakan atas dasar Permendikbud Nomor. 16 tahun 2014 tentang pemberlakuan Kurikulum 2006 dan Kurikulum 2013. Dan dilaksanakannya berpedoman dengan petunjuk teknis Keputusan Menteri Agama Nomor. 207 tahun 2014 tentang standar implementasi kurikulum madrasah di simpatika. Dalam penerapannya sejauh ini diupayakan dengan sebaik-baiknya. selama diterapkannya kurikulum 2013 ini, dapat mempermudah proses belajar dan mengajar karena dalam pembelajaran kurikulum 2013 menuntut agar peserta didik menjadi lebih aktif, berkembang, memiliki wawasan yang luas, kreatif, dan lebih percaya diri dalam menyampaikan pendapat. Selama penerapan kurikulum 2013 ini manajemen penerapan kurikulum 2013 menjadi semakin baik hampir seluruh pendidik menjadi lebih sadar akan tugasnya sebagai pendidik yang harus melengkapi segala administrasi yang diperlukan pada saat proses belajar mengajar berlangsung.

Dalam penerapan kurikulum 2013 ini ada sedikit banyaknya kendala yang dialami yaitu kurangnya pelatihan-pelatihan kepada pendidik dalam penerapan kurikulum 2013. Jadi, dalam hal ini masih banyak pendidik yang kurang paham bagaimana penerapan kurikulum 2013 yang benar dan dari segi administrasi masih ada juga sebagaian yang belum mengerti cara pembuatannya sendiri, masih dengan bantuan orang lain. Kurangnya media pembelajaran menjad salah satu kendala yang dialami selama penerapan 
kurikulum 2013 ini. Kendala yang sering dialami pada saat penerapan kurikulum 2013 ini hanya dalam penguasaan materi dan metode yang digunakan pada saat pembelajaran berlangsung. Tidak semua peserta didik pemikirannya sama, karena ada sebagian peserta didik yang kurang aktif apabila menggunakan metode ceramah dia paham dan saat diberi tugas untuk diskusi dia masih tidak mengerti. Jadi sebagai pendidik harus bisa melihat perkembangan setiap peserta didik.

\section{Daftar Pustaka}

Depdikbud. 1998. Management of Local Content Curriculum Implementation. Jakarta: Ditjen Dikdasmen Directorate of General Secondary Education.

Hamalik. 2003. Pendidikan Kurikulum.

Hamalik, Oemar. 2008. Manajemen Pengembangan Kurikulum. Bandung: Remaja Rosdakarya.

Majid, Abdul, and Chaerul Rochman. 2014. Pendekatan Ilmiah Dalam Implementasi Kurikulum. Bandung: PT Remaja Rosdakarya.

Porro, B. 2016. Talk It Out. Conflict Resolution in the Elemntary Classroom. United States Of Amerika: ASCD Association for Supervision and Curriculum Development.

Sani, Ridwan Abdullah. 2014. Pembelajaran Saintifik Untuk Implementasi Kurikulum 2013. Jakarta: Bumi Aksara.

Siregar, Erniati, Syafaruddin, and Muhammad Fuad Zaini. 2020. "The Leadership Of The School In Development Quality Culture In Student Learning In Mts State 2 Medan." International Journals of The Social Science, Education and Humanities 1(3).
Zaini, Muhammad Fuad. 2019. "The Implementation Of Learning Management In Class VIII Madrasa Tsanawiyah Islamiyah (MTS) YPI Batangkuis." In International Conference on Islamic Educational Management (ICIEM), https://scholar.google.co.id/citations?use $\mathrm{r}=9 \times \mathrm{xE} 5160 \mathrm{AAAAJ} \& \mathrm{hl}=\mathrm{id} \# \mathrm{~d}=\mathrm{gs} \_\mathrm{md} \_\mathrm{cit}$ a-

$\mathrm{d} \& \mathrm{u}=\% 2 \mathrm{Fcitations} \% 3$ Fview_op $\% 3$ Dvie W_citation $\% 26 \mathrm{hl} \% 3 \mathrm{Did} \% 26 \mathrm{user} \% 3 \mathrm{D} 9 \mathrm{x}$ E516oAAAAJ\%26citation for view\%3 D9xE5160AAAAJ\%3Au5 $\overline{\mathrm{H}} \mathrm{Hm} \mathrm{VD}$ uO 8C\%26tzom\%3D-420.

Zaini, Muhammad Fuad, and Syafaruddin Syafaruddin. 2020. "The Leadership Behavior of Madrasah Principals in Improving the Quality of Education in MAN 3 Medan." Jurnal Iqra': Kajian Ilmu Pendidikan 5(2): 95-106. https://journal.iaimnumetrolampung.ac.i d/index.php/ji/article/view/649.

\section{Profil Penulis}

Mayasari, lahir di Medan pada tanggal 18 April 1990, saat ini saat ini sedang melanjutkan studi di Universitas Islam Negeri Sumatera Utara Medan dan berprofesi sebagai guru.

Mahanum, lahir di Binanga pada tanggal 06 Juni 1985, saat ini sedang melanjutkan studi di Universitas Islam Negeri Sumatera Utara Medan.

Usiono, Saat ini berprofesi sebagai Dosen di Fakultas Tarbiyah dan Ilmu keguruan Universitas Islam Negeri Sumatera Utara Medan 